\title{
Rapid inactivation of waterborne bacteria using boron-doped diamond electrodes
}

\author{
C. Heim • M. Ureña de Vivanco • M. Rajab • \\ E. Müller • T. Letzel $\cdot$ B. Helmreich
}

Received: 18 April 2013/Revised: 13 October 2014/Accepted: 17 November 2014/Published online: 2 December 2014

(C) Islamic Azad University (IAU) 2014

\begin{abstract}
The application of a boron-doped diamond electrode in electrochemical water disinfection was investigated with respect to its inactivation potential of three indicator microorganisms. Drinking water and the effluent of a wastewater treatment plant spiked with Escherichia coli, Enterococcus faecium and Pseudomonas aeruginosa were electrolysed under different conditions in a batch reactor. All three bacteria species could be successfully inactivated in drinking water. The disinfection rate depended on the applied charge, with far more efficiency at high current densities (208 and $333 \mathrm{~mA} / \mathrm{cm}^{2}$ ) under high ozone concentrations measured in contrast to low current densities $\left(42 \mathrm{~mA} / \mathrm{cm}^{2}\right)$ where bacterial inactivation was rather driven by hydroxyl radicals. When oxidising a target pharmaceutical compound in the wastewater treatment plant effluent, the water matrix exhibited an ozone scavenging effect. The resulting decrease in the efficiency could not be detected for the disinfection experiments in the complex water matrix compared to drinking water, which indicates a different disinfection mechanism, probably due to reactive chlorine species.
\end{abstract}

Keywords Electrochemical oxidation - Diamond electrode - Water disinfection - Enterococcus faecium . Escherichia coli $\cdot$ Pseudomonas aeruginosa

C. Heim $(\bowtie) \cdot$ M. Ureña de Vivanco · M. Rajab · E. Müller ·

T. Letzel · B. Helmreich

Chair of Urban Water Systems Engineering, Technische

Universität München, Am Coulombwall, 85748 Garching,

Germany

e-mail: c.heim@tum.de

\section{Introduction}

Water quality standards are highly regulated in different areas (domestic distribution, wastewater treatment plants and clinical applications) in order to minimise the risk of waterborne diseases caused by bacterial contamination. At the same time, with antibiotic resistance on the rise, it is imperative to have treatment methods that reliably inactivate microbial contaminations (Figueras and Borrego 2010). Therefore, disinfection processes play an important role in ensuring acceptable biological standards in different areas of water applications.

Various disinfection technologies such as chlorination, UV disinfection, membrane filtration and ozonation are currently in use for water treatment (Caslake et al. 2004; Gibson and Schwab 2011; Griessler et al. 2011). However, their utilisation is limited through several shortcomings such as operational safety, formation of unwanted by-products and high costs for operation and maintenance (Lazarova et al. 1999; Griessler et al. 2011; Yao et al. 2011).

The application of electrochemical oxidation as an alternative disinfection technology has proven effective against a broad spectrum of microorganisms (Jeong et al. 2006; Ndjomgoue-Yossa et al. 2014). It falls into the category of advanced oxidation processes (AOPs), which are mainly characterised by the formation of highly reactive hydroxyl (OH) radicals (Schmalz et al. 2008). The generation of a mixture of reactive species including ozone, hydrogen peroxide, various radicals and eventually chlorine-based compounds promotes the oxidation reaction. In contrast to common disinfection methods, the disinfectants are produced in situ, directly at the point of use without the addition and storage of chemicals (da Silva et al. 2003; Bergmann 2010). Electrochemical disinfection can easily be included into industrial processes. Its operation, even in 
turbid water, is simple, and the economic investment is manageable (Fryda et al. 2003; Heim and Glas 2011).

In the 1980s, a highly efficient technology emerged which used boron-doped diamond (BDD) electrodes to produce electrochemical oxidants in situ (Pleskov et al. 1987; Anglada et al. 2009). What sets these electrodes apart is their inertness and high over-potential for the formation of oxygen at the anode. Therefore, the generation of $\mathrm{OH}$ radicals is driven at low temperatures and through further reactions, the formation of other oxidative species, mainly ozone and hydrogen peroxide, can also occur (Michaud et al. 2003). Conductivity is achieved through doping of the crystalline diamond layer with boron. The quantities of oxidants depend on the applied current density (Fryda and Matthée 2006; Bergmann 2010).

Apart from $\mathrm{OH}$ radicals, ozone has the highest oxidation potential (2.07 vs. 2.70 V for $\mathrm{OH}$ radicals; Cho et al. 2003). Moreover, it is characterised by a relatively long half-life time of 20-30 min at $20{ }^{\circ} \mathrm{C}$, depending on the water matrix and $\mathrm{pH}$ (Khadre et al. 2001). This allows for direct and selective oxidation of organic and inorganic compounds (von Gunten 2003a). Ozone has the ability to oxidise proteins located on the cell surface by ozonolysis (Criegée 1975). After ozone diffuses through the biological membrane, it can damage intracellular components. The disinfection activity of ozonated water towards microorganisms including bacteria, yeasts and even fungal spores has been described in several studies (Eliasson et al. 1987; Hunt and Mariñas 1997; Tröster et al. 2004; Jeong et al. 2006). Today ozone is widely used for the treatment of drinking and wastewater (Lazarova et al. 1999; Heim and Glas 2011). The disinfection potential of ozone was found to exceed that of chlorine, although the latter also attacks intracellular compounds (Cho et al. 2010). In aqueous solutions, ozone is unstable and degrades to oxygen through a chain reaction under the formation of primarily $\mathrm{OH}$ radicals. Oxidation through $\mathrm{OH}$ radicals is a rapid and rather unselective process with rate constants in the range of $10^{6}-10^{9} \mathrm{M}^{-1} \mathrm{~s}^{-1}$ (Elovitz and von Gunten 1999). This reaction is very useful for the removal of organic contaminants from wastewater (Andreozzi et al. 1999; da Silva et al. 2003).

In situ oxidant production with BDD electrodes can be performed with a relatively small energy input compared to classical disinfection due to the high oxidant yield of the electrode. Losses that are associated with oxidant dissolution are significantly reduced when production occurs in situ. This makes disinfection of drinking and wastewater with BDD electrodes a promising alternative to commonly used oxidation techniques (Kraft 2007; Anglada et al. 2011; Zhu et al. 2008). Up to the present, only a relatively small number of studies have been conducted to characterise disinfection with BDD electrodes. The numbers, however, are growing, which indicates the increasing interest in this technique (Tanner et al. 2004; Jeong et al. 2006; Schmalz et al. 2009; Frontistis et al. 2011; Haaken et al. 2012; Liu et al. 2012). However, there is a lack of mechanistic investigations in real water matrices.

In the current research, a BDD electrode was applied to study the disinfection mechanisms for selected waterborne microorganisms under varying electrode conditions in different water matrices, namely drinking water and wastewater treatment plant (WWTP) effluent. The bacteria species Escherichia coli, Pseudomonas aeruginosa and Enterococcus faecium were chosen. E. coli and E. faecium represent indicator microorganisms for faecal contaminations in water and therefore are adequate parameters for water quality control (Mtethiwa et al. 2008; Figueras and Borrego 2010). P. aeruginosa is ubiquitous in water and soil. Due to its resistance against various antibiotics and disinfectants, it has been reported as a pathogen in the clinical environment and also as a water contaminant (Lambert 2002; Lee et al. 2002; Schmalz et al. 2008). Additionally, the bacterial inactivation behaviour was evaluated in the presence of the target pharmaceutical compound carbamazepine (CBZ), which is known to be also oxidised by ozone and $\mathrm{OH}$ radicals (Huber et al. 2005; Menapace et al. 2008). The formation of disinfection byproducts is additionally estimated through the adsorbable, organically bound halogens parameter (AOX). The experiments were conducted from April to June 2011 at the Chair of Urban Water Systems Engineering, Technische Universität München.

\section{Materials and methods}

\section{Experimental setup}

Experiments were conducted with a CONDIAPURE ${ }^{\circledR}$ test system (CONDIAS GmbH, Itzehoe, Germany) using a DIACHEM $^{\circledR}$ electrode stack (CONDIAS) integrated into an optically accessible glass reactor with a total height of 253 and $42 \mathrm{~mm}$ diameter (Esau \& Hueber GmbH, Schrobenhausen, Germany). A schematic configuration of the operation unit is displayed in Fig. 1. In situ ozone generation was performed with a single anode/cathode pair and a surface of $24 \times 50 \mathrm{~mm}^{2}$ per electrode. The electrode substrate material was niobium, coated with a 1 - to 5- $\mu$ mthick boron-doped diamond layer. Electrode currents could be varied through a DC source with a maximum output current of $10 \mathrm{~A}$ and a maximum output voltage of $35 \mathrm{~V}$. Current densities of 42, 208 and $333 \mathrm{~mA} / \mathrm{cm}^{2}$ were applied. Three litres of bacteria solutions were prepared in a glass vessel (tempered to $20 \pm 1{ }^{\circ} \mathrm{C}$ ), which was connected to 


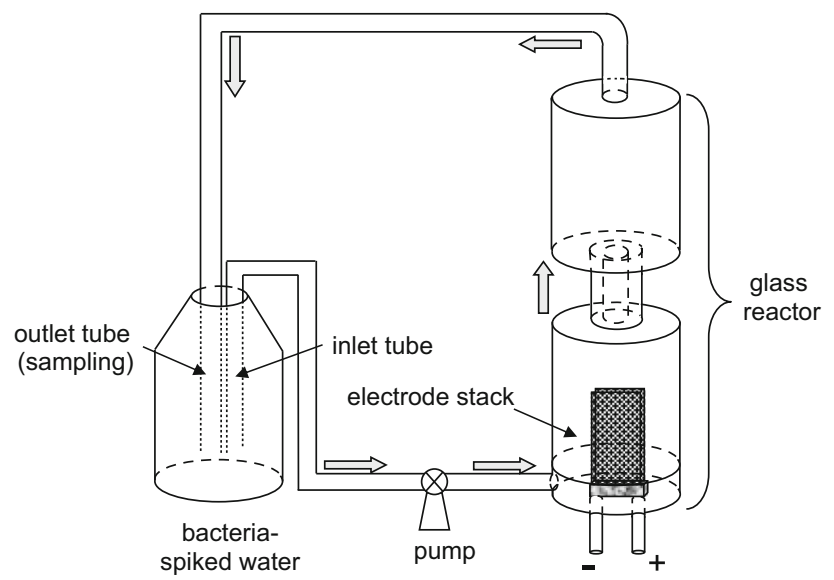

Fig. 1 Schematic illustration of the BDD electrode and the reactor unit

the operation unit with an inlet and outlet tube. The reaction solution was circulated through the glass reactor by a centrifugal pump (PY-2071, Speck Pumpen, Hilpoltstein, Germany) at a flow rate of $4 \mathrm{~L} / \mathrm{min}$. All experiments were carried out twice.

\section{Water matrices}

Experiments were carried out in synthetic soft drinking water (drinking water), containing $20 \mathrm{mg} / \mathrm{L}$ chloride $(\mathrm{NaCl}), \quad 0.1 \mathrm{mg} / \mathrm{L}$ bromide $(\mathrm{KBr}), \quad 10 \mathrm{mg} / \mathrm{L}$ nitrate $\left(\mathrm{NaNO}_{3}\right)$ and $60 \mathrm{mg} / \mathrm{L}$ sulphate $\left(\mathrm{Na}_{2} \mathrm{SO}_{4}\right)$ in deionised water (deioniser "Milli-Q Plus 185", conductivity $0.055 \mu \mathrm{S} / \mathrm{cm}$ at $20^{\circ} \mathrm{C}$ ), with a total hardness of $0.9 \mathrm{mmol} /$ $\mathrm{L}$ and at $\mathrm{pH}$ 8.9. The second water matrix was actual wastewater collected from the municipal WWTP Garching, Germany, after secondary sedimentation before UV irradiation (WWTP effluent). The total organic carbon (TOC) content varied between 6 and $13 \mathrm{mg} / \mathrm{L}$ at $\mathrm{pH} 8.0$.

The water was spiked with initial bacteria concentrations of approx. $10^{7}-10^{8} \mathrm{CFU} / \mathrm{mL}$ from strains of $E$. coli (ATCC 11775), P. aeruginosa (ATCC 10145) and E. faecium (ATCC 19434). For oxidation experiments, the target compound CBZ (Sigma-Aldrich, Taufkirchen, Germany) was added at a starting concentration of $5.5 \mu \mathrm{mol} / \mathrm{L}$.

\section{Sampling}

Samples were taken from the outlet tube (see Fig. 1) after $0,1,5,10,15,20$ and $30 \mathrm{~min}$ of disinfection for microbial analyses as well as to determine residual ozone, chloride, dissolved organic carbon (DOC) and AOX concentrations.

Samples from CBZ-spiked water were taken after 2, 5, 10 and $15 \mathrm{~min}$, filtered through $0.2 \mu \mathrm{m}$ Pleomax PVDF, vortexed and analysed with mass spectrometry (MS).
Microbial analysis

Viable counts of E. coli, E. faecium und P. aeruginosa were determined using international standard guidelines for drinking water and surface water. E. coli samples were analysed according to the bathing water directive (Council directive 2006/7/EC of 15 February 2006). Briefly, E. coli solutions were cultivated in 4-methylumbelliferyl- $\beta$-Dglucuronide (MUG) lauryl sulphate bouillon. Dilution series were made in PBS solution and incubated for $24 \mathrm{~h}$ at $37 \pm 1^{\circ} \mathrm{C}$. E. coli numbers were calculated according to the most probable number (MPN) method. Determination of E. faecium and P. aeruginosa bacteria was performed based on the drinking water directive (Council directive 1998/83/EC of 3 November 1998). Samples were filtered through $0.45 \mu \mathrm{m}$ cellulose nitrate filters (Sartorius, Göttingen, Germany). E. faecium was cultivated according to ISO $7899-2$ and incubated for $48 \mathrm{~h}$ at $37 \pm 1{ }^{\circ} \mathrm{C}$. $P$. aeruginosa solutions were diluted with $1 / 4$ concentrated Ringer's solution prior to the filtration according to ISO 16266. Filters were then placed on selective agar (ISO 12780:2002 CP67.1) and incubated for $48 \mathrm{~h}$ at $37 \pm 1{ }^{\circ} \mathrm{C}$.

Based on the change in the bacterial count of the sample after a certain disinfection period, the inactivation rate was calculated as the logarithmic reduction of bacteria (log $\mathrm{N} / \mathrm{N}_{0}$ ), where $\mathrm{N}_{0}$ represents the initial bacterial concentration and $\mathrm{N}$ the bacterial count at the respective sampling time.

\section{Chemical analysis}

Parallel to the disinfection experiments, ozone concentrations were additionally quantified as residual ozone by photometric measurement at $610 \mathrm{~nm}$ after decolorisation of indigo bisulphonate in the presence of ozone. The analyses were performed based on the descriptions given by Bader and Hoigné (1981) and Yates and Stenstrom (2000). Instead of phosphate buffer, phosphoric acid was employed. Samples containing bacteria were filtered using a $0.45 \mu \mathrm{m}$ polyvinylidene difluoride (PVDF) filter to avoid any diffractive effects during the photometric measurement.

The $\mathrm{pH}$ was controlled based on Standard Methods (SM) 4500- $\mathrm{H}^{+}$(Eaton et al. 2005). Chemical analysis of DOC was performed with an Elementar High TOC II-Analyser according to SM 5310 after filtration through a $0.45 \mu \mathrm{m}$ polypropylene membrane filter. For measurement of AOX, $500 \mathrm{~mL}$ of sample solution were collected in a brown glass bottle and stored at $4{ }^{\circ} \mathrm{C}$. Further oxidation was prevented by addition of $5.0 \mathrm{~mL} 1 \mathrm{mM}$ sodium sulphite solution; the $\mathrm{pH}$ was adjusted $<\mathrm{pH} 1$ with $1 \mathrm{~mL} 65 \% \mathrm{HNO}_{3}$. AOX was determined according to SM 5320 using an ABIMED TOX-10 organic halogen analyser. Chloride concentrations 
were analysed by ion chromatography with a DIONEX ICS-1000 device according to SM 4110.

\section{Mass spectrometry}

A time-of-flight (ToF) MS (Agilent 6230 Accurate-Mass ToF MS) was used for CBZ analysis. Samples were directly injected into the mass spectrometer with a syringe pump (flow rate $5.0 \mu \mathrm{L} / \mathrm{min}$ ). Generation of the ions for measurement was performed with a multimode ion source (MMI) in ESI mode. A capillary voltage of 2,500 V and a charging voltage of 2,000 $\mathrm{V}$ were applied. The drying gas was a nitrogen stream of $5.0 \mathrm{~L} / \mathrm{min}$ at $250{ }^{\circ} \mathrm{C}$. The nebuliser pressure was set to $20 \mathrm{psig}$. Measurements in negative ionisation mode were carried out in the $\mathrm{m} / \mathrm{z}$-range from 70 to 1,000 . The signals were recorded for $1 \mathrm{~min}$ and the average spectrum was used for evaluation.

\section{Results and discussion}

Disinfection using BDD electrodes can be influenced by electrode and reactor parameters as well as extrinsic factors. This study focuses on possible effects of a variation of the current density on bacterial inactivation and on the impact of the water matrix composition. Inactivation of E. coli was tested at current densities of 42, 208 and $333 \mathrm{~mA} / \mathrm{cm}^{2}$ in drinking water in order to optimise electrode conditions and ozone output. As the electrode geometry was not modified during the experiments, the current density was altered only through the applied current. Since the total amount of oxidative agents introduced into the system during electrolysis cannot be measured, determination of residual ozone concentrations was the method of choice to trace the reaction.

\section{Current effect}

First, the role of ozone in the disinfection experiments had to be determined. The dependency of bacteria inactivation on disinfectant concentration and contact time can generally be displayed as time-concentration (ct) curves according to the law of Chick and Watson (Gottschalk et al. 2010). Figure 2a shows bacteria inactivation curves of $E$. coli versus ozone concentration and contact time under variation of the applied current density. Initial bacteria numbers varied between $10^{7}$ and $10^{8} \mathrm{CFU} / \mathrm{mL}$. For each current density, complete inactivation, or roughly a log-7-8 removal, was observed at a ct value of approximately $6(\mathrm{mg} \mathrm{min}) / \mathrm{L}$. A biphasic trend in bacteria removal could be noticed, whereby the initial removal phase was more rapid than at the end. In our investigations, the displayed ct curves refer to the ozone exposures and consider
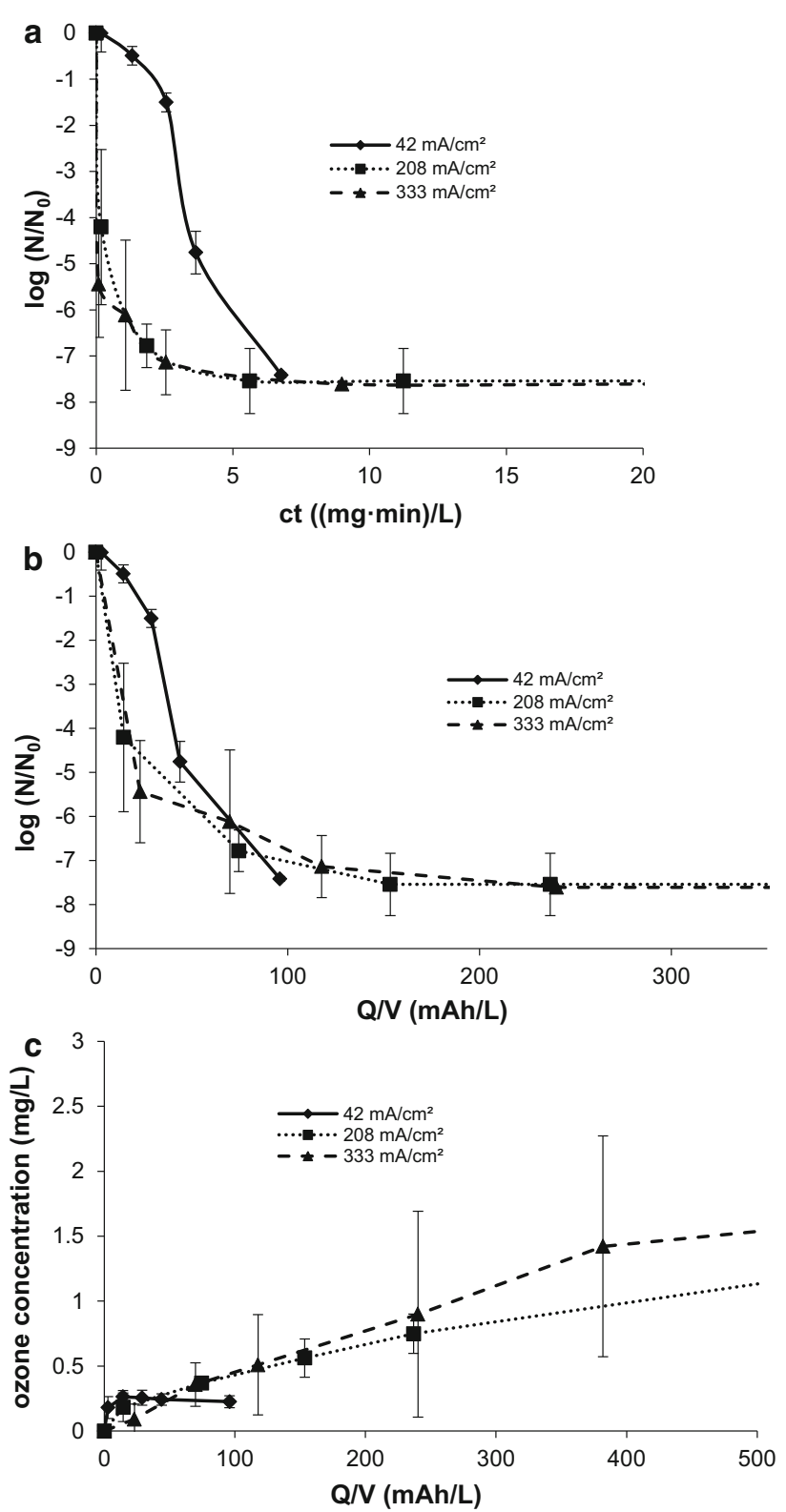

Fig. 2 E. coli inactivation displayed as ct curves (a) and the applied charge per volume (b) and the corresponding residue ozone curves (c) at three different current densities

only residual ozone concentrations. Inactivation of $4.2 \mathrm{log}$ units could be achieved at a ct value of $0.18(\mathrm{mg} \mathrm{min}) / \mathrm{L}$ at both current densities of 208 and $333 \mathrm{~mA} / \mathrm{cm}^{2}$. The identical ct curves at those current densities reflect the strong dependency of bacterial inactivation and lie in the range of the other literature data (Tanner et al. 2004). However, no comparison can be drawn in terms of the applied current densities as a different technology was used for electrochemical ozone generation. In contrast, the low current density of $42 \mathrm{~mA} / \mathrm{cm}^{2}$ differed from that tendency with a delayed reduction of $E$. coli (ct value approx. 3.5 
(mg min)/L), which clearly indicates another, less effective disinfection mechanism in this case. Since for current densities below $100 \mathrm{~mA} / \mathrm{cm}^{2}$ also the ozone formation efficiency was found to be significantly lower and the generation of $\mathrm{OH}$ radicals favoured (Ureña de Vivanco et al., in preparation), we postulate that bacterial inactivation at low current densities was not predominantly driven by ozone, but rather by the attack through $\mathrm{OH}$ radicals. These radicals could instantly and non-selectively react with cellular components of the microorganisms and cause damage basically to the outer cell membrane. However, major damage and bacterial inactivation are rather achieved through reactions with the DNA (von Gunten 2003 b). In contrast to ozone, $\mathrm{OH}$ radicals are not able to penetrate into the cells and as a consequence of their shortlived existence, their reaction radius is strongly limited. Therefore, the disinfection potential of $\mathrm{OH}$ radicals has been reported to be lower than that of ozone (Wolfe et al. 1989; Cho et al. 2003).

Variation of experimental parameters such as the current density and the volume of the bacteria solution led to different treatment times. Hence, it was necessary to optimise and standardise those conditions for further experimental setups. Thus, the above described inactivation rates are correlated to the applied current per volume, which is linked to the disinfection time (Fig. 2b). Analogous to Fig. 2a, the disinfection curves are almost identical for the high current densities of 208 and $333 \mathrm{~mA} / \mathrm{cm}^{2}$, in particular when considering the initial disinfection phase. However, the low current density of $42 \mathrm{~mA} / \mathrm{cm}^{2}$ displayed a remarkable deviation from those curves, particularly below $50 \mathrm{mAh} / \mathrm{L}$. Thus, reduction of bacteria counts at high current densities appeared independent of the applied current rate, whereas disinfection at the low current density appeared less effective. Considering time specifications, it took less than $5 \mathrm{~min}$ to inactivate all $E$. coli cells at a current density of $333 \mathrm{~mA} / \mathrm{cm}^{2}$, whereas $30 \mathrm{~min}$ were required at $42 \mathrm{~mA} / \mathrm{cm}^{2}$. The dependency of disinfection with the BDD electrode on the applied current density has been described by other authors (Schmalz et al. 2009; Liu et al. 2012). This was also evident in our experiments as seen by the shift in the disinfection mechanism towards less effective oxidants when the current density was lowered to $42 \mathrm{~mA} / \mathrm{cm}^{2}$. However, as soon as the current density was increased to values above $100 \mathrm{~mA} / \mathrm{cm}^{2}$, ozone was the predominant oxidant produced, and the inactivation depended only on the total charge input (which was also reflected by the energy expenditure) instead of the applied current density.

A comparison of the enrichment of residual ozone over the applied current per volumes at different current densities in the bacteria-spiked solutions is given in Fig. 2c. Maximum ozone concentrations varied between $0.25 \mathrm{mg} / \mathrm{L}$ using $42 \mathrm{~mA} / \mathrm{cm}^{2}$ and $1.5 \mathrm{mg} / \mathrm{L}$ at $333 \mathrm{~mA} / \mathrm{cm}^{2}$. In a previous study, the authors have described a linear correlation between current densities and residual ozone concentrations in various waters (Heim et al. 2011). The same tendency could be observed for ozone during our disinfection experiments.

\section{Energy consumption}

Higher current densities do not only result in more ozone but also in a higher energy consumption. Energy consumption for a log-5 reduction of $E$. coli cells and inactivation of all spiked bacteria (log-7.4 reduction) was calculated based on values from electrolysis of synthetic drinking water and WWTP effluent (Table 1). Process intrinsic energy $\left(E_{\text {pro }}\right)$ considered only the electricity consumption of the electrolytic process and was based on ozone formation at the electrode. The total energy consumption $\left(E_{\text {tot }}\right)$ also included technology-specific energy consumption, e.g. for pumping. Operation of the electrode at a current density of $42 \mathrm{~mA} / \mathrm{cm}^{2}$ resulted in the lowest energy requirement regarding process intrinsic energy with $0.14 \mathrm{Wh} / \mathrm{L}$ for $\log -5$ removal and $0.25 \mathrm{Wh} / \mathrm{L}$ for complete inactivation. However, since the treatment time until inactivation was much longer as compared to higher current densities, the total energy consumption was the highest for the low current density. The percentage of the energy

Table 1 Calculated process intrinsic (pro) and total (tot) electrical energy consumption for $\log -5$ removal as well as complete inactivation (log-7.4) of E. coli

\begin{tabular}{|c|c|c|c|c|c|c|c|c|c|}
\hline \multirow{2}{*}{$\begin{array}{l}\text { Water } \\
\text { matrix }\end{array}$} & \multirow{2}{*}{$\begin{array}{l}\text { Current density } \\
\left(\mathrm{mA} / \mathrm{cm}^{2}\right)\end{array}$} & \multicolumn{4}{|l|}{ Log-5 removal } & \multicolumn{4}{|c|}{ Complete inactivation } \\
\hline & & $\begin{array}{l}\text { Charge input } \\
(\mathrm{mAh} / \mathrm{L})\end{array}$ & $\begin{array}{l}\text { Time } \\
(\min )\end{array}$ & $\begin{array}{l}E_{\log 5, \text { pro }} \\
(\mathrm{Wh} / \mathrm{L})\end{array}$ & $\begin{array}{l}E_{\log 5, \text { tot }} \\
(\mathrm{Wh} / \mathrm{L})\end{array}$ & $\begin{array}{l}\text { Charge input } \\
(\mathrm{mAh} / \mathrm{L})\end{array}$ & $\begin{array}{l}\text { Time } \\
(\min )\end{array}$ & $\begin{array}{l}E_{\log 7.4, \text { pro }} \\
(\mathrm{Wh} / \mathrm{L})\end{array}$ & $\begin{array}{l}E_{\log 7.4, \text { tot }} \\
(\mathrm{Wh} / \mathrm{L})\end{array}$ \\
\hline \multirow{3}{*}{$\begin{array}{l}\text { Drinking } \\
\text { water }\end{array}$} & 42 & 49 & 20 & 0.14 & 8.69 & 96 & 30 & 0.25 & 15.7 \\
\hline & 208 & 34 & 2.5 & 0.17 & 1.09 & 143 & 10 & 0.75 & 4.83 \\
\hline & 333 & 21 & 1 & 0.74 & 1.10 & 197 & 10 & 8.74 & 13.1 \\
\hline $\begin{array}{l}\text { WWTP } \\
\text { effluent }\end{array}$ & 208 & 61 & 5 & 0.27 & 2.13 & 127 & 10 & 0.63 & 1.00 \\
\hline
\end{tabular}


required for pumping had a considerable impact at prolonged treatment times. The most advantageous configuration was $208 \mathrm{~mA} / \mathrm{cm}^{2}$ with a total energy consumption of $1.09 \mathrm{Wh} / \mathrm{L}$ for a $\log -5$ reduction and $4.83 \mathrm{Wh} / \mathrm{L}$ for a $\log$ 7.4 reduction of $E$. coli. A further increase of the current density yielded significantly higher energy values for both process intrinsic and total energy consumption.

Electrolysis of WWTP effluent instead of synthetic drinking water almost doubled energy values for a $\log -5$ removal from 0.17 to $0.27 \mathrm{Wh} / \mathrm{L}$, but for complete inactivation, the requirement was comparable. The total energy expenditure in WWTP effluent $(2.13 \mathrm{Wh} / \mathrm{L})$ was comparable to the literature data with a total consumption of 2.0-2.6 Wh/L for a $\log -5$ reduction of $E$. coli using the BDD electrode (Haaken et al. 2012). The high energy efficiency of the diamond electrode compared to other AOPs, including treatment with $\mathrm{UV} / \mathrm{H}_{2} \mathrm{O}_{2}$, which is currently in use for disinfection in wastewater treatment plants, could be shown before in a comparative study (Ureña de Vivanco et al. 2013).

Since both current densities of 208 and $333 \mathrm{~mA} / \mathrm{cm}^{2}$ were shown to be equally efficient in disinfection per unit charge, $208 \mathrm{~mA} / \mathrm{cm}^{2}$ was chosen as standard configuration for further disinfection experiments due to the lower energy consumption.

\section{Water matrix effect}

Organic and inorganic water components generally reduce residual ozone concentrations, thus demanding higher ozone doses or contact times for oxidative degradation and bacterial inactivation (Burleson et al. 1975; Hoigné and Bader 1983a, b; Cho et al. 2003; von Gunten 2003a). To

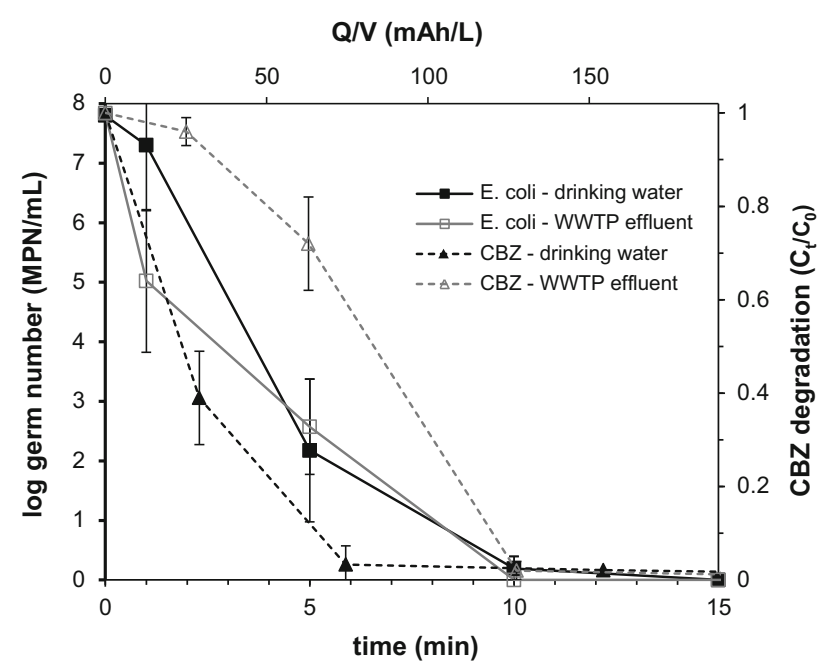

Fig. 3 Comparison of E. coli inactivation and CBZ degradation at $208 \mathrm{~mA} / \mathrm{cm}^{2}$ in drinking water and WWTP effluent examine this influence on bacterial disinfection, inactivation rates of $E$. coli in synthetic drinking water were compared with WWTP effluent. To gain further information about the disinfection mechanism, treatment of $E$. coli with the BDD electrode was performed in the presence of the target compound CBZ at a current density of $208 \mathrm{~mA} /$ $\mathrm{cm}^{2}$. Approximately $70 \mathrm{mAh} / \mathrm{L}(6 \mathrm{~min})$ were required to almost fully oxidise CBZ in soft water, whereas nearly $120 \mathrm{mAh} / \mathrm{L}(10 \mathrm{~min})$ were required to attain the same level of degradation in the WWTP effluent (Fig. 3). Thus, a strong dependency of CBZ degradation on the complexity of the water matrix could be observed. In comparison, all $E$. coli cells were inactivated in both water matrices at around $120 \mathrm{mAh} / \mathrm{L}$. The initial disinfection appeared even more efficient in the WWTP effluent compared to the drinking water matrix. Thus, bacterial inactivation was not subject to the same matrix effect as observed for CBZ degradation and must have been driven by another mechanism in wastewater than in drinking water. In chloriderich water, chlorine and hypochlorite, both commonly used as disinfectants, are by-products formed from reactions with $\mathrm{OH}$ radicals (von Gunten 2003b). Due to the high chloride content in the WWTP effluent $(40.7 \mathrm{mg} / \mathrm{L}$ in drinking water vs. $217 \mathrm{mg} / \mathrm{L}$ in the WWTP effluent), it is likely that those oxidation products formed and compensated for the lower ozone concentrations. A clear increase of inactivation ratios at higher chloride concentrations has been shown through experiments with water and varying chloride concentrations (Yao et al. 2011; Liu et al. 2012). Furthermore, Wolfe et al. (1989) detected a greater bactericidal effect of free chlorine in surface water compared to ozone. In our investigations with WWTP effluent, the role of $\mathrm{OH}$ radicals as a disinfectant was most likely negligible as it is not possible for the reactive radicals to diffuse away from the electrode and immediately react with other water components.

\section{Disinfection of different bacteria species}

Different bacteria species can show variable sensitivity towards disinfectants. Electrochemical inactivation of the gram-negative model organisms $E$. coli and $P$. aeruginosa and the gram-positive E. faecium in synthetic drinking water using the BDD electrode was therefore investigated. Since all experiments were conducted at the same current density of $208 \mathrm{~mA} / \mathrm{cm}^{2}$, the specific charge input, and therefore also the disinfection progress, can be directly correlated to the disinfection time. Bacterial reduction rates of at least 5 log-units could be observed for all three model organisms during the first $75 \mathrm{mAh} / \mathrm{L}$ ( $5 \mathrm{~min}$ ), followed by a continuous, but slower inactivation (Fig. 4a). Inactivation of all organisms was achieved within $150 \mathrm{mAh} / \mathrm{L}$ (10 min). The inactivation curves of the different species and thus the 

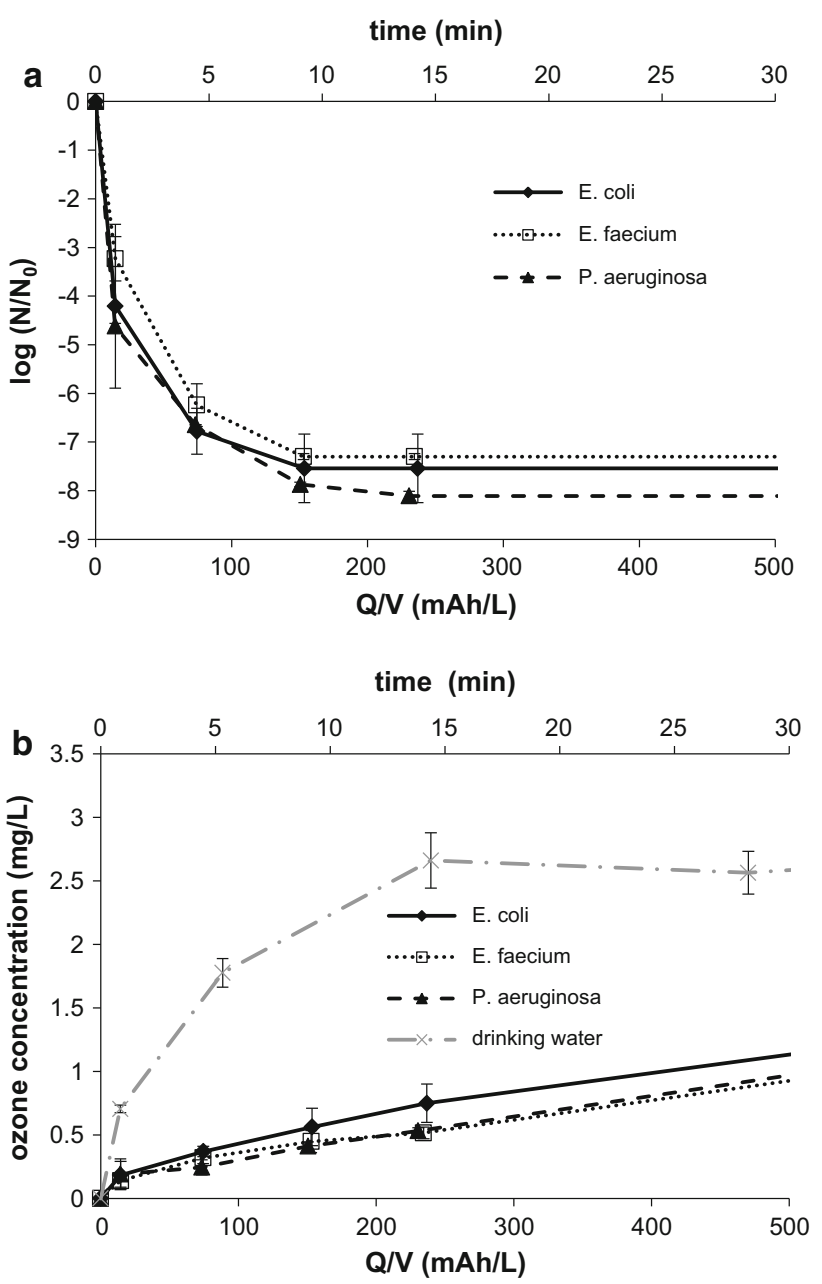

Fig. 4 Inactivation of E. coli, P. aeruginosa and E. faecium (a) and ozone concentrations in bacteria-spiked and pure drinking water (b) at $208 \mathrm{~mA} / \mathrm{cm}^{2}$

sensitivity towards disinfection with the BDD electrode were similar, but appeared slightly higher for the gramnegative bacteria in comparison to the gram-positive $E$. faecium. However, this difference was marginal. Other studies have also reported a quick inactivation of gramnegative bacteria such as $E$. coli and $P$. aeruginosa upon ozonation (Restaino et al. 1995). In contrast, the outer cell wall of gram-positive bacteria like E. faecium has been described as being more resistant to oxidising agents due to its complex composition. The cell walls of gram-positive bacteria consist of a thick structure of several peptidoglycan layers, whereas gram-negative species are characterised by an outer membrane containing lipoproteins, lipopolysaccharides and a thin layer of peptidoglycans. It is reported that $\mathrm{N}$-acetyl glucosamine present in the peptidoglycan layer could not be oxidised by ozone in aqueous solution (Khadre et al. 2001). Our data account for minor disparities as a consequence of different cell wall constitutions in gram-positive and gram-negative bacteria.
Residual ozone concentrations were almost identical for all bacterial solutions and were characterised by a continuous increase during the disinfection experiments (Fig. 4b). Only the ozone curves from E. coli disinfection differed slightly from the ozone production determined for the disinfection of $P$. aeruginosa and E. faecium. The course of residual ozone in the drinking water without bacteria was significantly higher than ozone production detected in the bacteria-spiked disinfection experiments. Even after complete inactivation of all bacteria (from $150 \mathrm{mAh} / \mathrm{L}$ onwards), residual cell material in the bacteriaspiked solutions was further oxidised by ozone. The amounts of residual ozone can be expected to adapt to that of pure drinking water when the oxidation of the cell material as well as other organic and inorganic matter is completed.

Oxidation of organic and inorganic matter

DOC concentration changes indicate to which degree organic matter was mineralised during the oxidation process. According to the literature data, more than $3 \mathrm{~g}$ of ozone are required to oxidise $0.2 \mathrm{~g}$ of DOC (Gottschalk et al. 2010). Table 2 includes DOC, AOX and chloride concentrations before and after disinfection in drinking water and WWTP effluent. In drinking water, DOC concentrations rose from 3.8 to $6.6 \mathrm{mg} / \mathrm{L}$, whereas in the WWTP effluent only a slight increase from 5.4 to $6.0 \mathrm{mg} / \mathrm{L}$ was observed. These findings represent the conversion of complex organic matter, for instance residual cellular material, into transformation products during the oxidation process. Since residual ozone concentrations in the current experiments were around $2.5 \mathrm{mg} / \mathrm{L}$ for non-contaminated drinking water (containing few ozone-consuming compounds), this relatively low rate of "excess ozone" is likely to be insufficient to remove all organic material in the bacteria-spiked solutions. The conversion of complex organic matter into better degradable compounds carries

Table 2 Concentrations of DOC, AOX and chloride before and after disinfection experiments in drinking water and in the WWTP effluent (n.d. $<10 \mu \mathrm{g} / \mathrm{L}$ )

\begin{tabular}{|c|c|c|c|c|c|c|}
\hline \multirow[t]{2}{*}{ Time point } & \multicolumn{3}{|c|}{ Drinking water ${ }^{a}$} & \multicolumn{3}{|c|}{ WWTP effluent ${ }^{\mathrm{b}}$} \\
\hline & $\begin{array}{l}\text { DOC } \\
(\mathrm{mg} / \mathrm{L})\end{array}$ & $\begin{array}{l}\text { AOX } \\
(\mu \mathrm{g} / \mathrm{L})\end{array}$ & $\begin{array}{l}\mathrm{Cl}^{-} \\
(\mathrm{mg} / \\
\mathrm{L})\end{array}$ & $\begin{array}{l}\text { DOC } \\
(\mathrm{mg} / \mathrm{L})\end{array}$ & $\begin{array}{l}\text { AOX } \\
(\mu \mathrm{g} / \mathrm{L})\end{array}$ & $\begin{array}{l}\mathrm{Cl}^{-} \\
(\mathrm{mg} / \\
\mathrm{L})\end{array}$ \\
\hline $\begin{array}{l}\text { Before } \\
\text { disinfection }\end{array}$ & 3.8 & n.d. & 40.7 & 5.4 & 13.3 & 217 \\
\hline $\begin{array}{l}\text { After } \\
\text { disinfection }\end{array}$ & 6.6 & n.d. & 36.5 & 6 & 158 & 190 \\
\hline
\end{tabular}

${ }^{a}$ Disinfection was carried out for $30 \mathrm{~min}$

b Disinfection was carried out for $60 \mathrm{~min}$ 
the risk of bacterial regrowth as those substances can be more easily utilised by microorganisms. This might especially apply to the WWTP effluent in our study, which was characterised by a high DOC. Trace amounts of ozone as well as other reactive disinfectants, for instance chlorine, will in contrast act preventively.

In water containing inorganic ions, cross-reactions between organic and inorganic substances are also possible. These reactions can subsequently lead to halogenated organic by-product formation. Such by-products are unwanted as they might be toxic or even carcinogenic (Kümmerer et al. 1998). AOX represent all adsorbable halogenated organic compounds in a water matrix as a sum parameter, predominantly resulting from chemical reactions of free chlorine with organic matter (Schmalz et al. 2009). Thus, measurement of AOX allows estimating byproduct formation. Even though no threshold value exists for AOX in drinking water and the majority of them are non-toxic, a maximum discharge limit of $0.7 \mathrm{mg} / \mathrm{L}$ for integrated recovered paper mills has been prescribed in the Integrated Pollution Prevention and Control Directive (Council directive 2008/1/EC of 15 January 2008). The application of the BDD electrode in biologically treated sewage has been reported to generate low amounts of AOX, with a maximum value of $127 \mu \mathrm{g} / \mathrm{L}$ being recorded (Haaken et al. 2012). In the current study, AOX concentrations were below the detection limit of $10 \mu \mathrm{g} / \mathrm{L}$ in drinking water, whereas in the WWTP effluent, AOX levels were found to increase from $13.3 \mu \mathrm{g} / \mathrm{L}$ up to $158 \mu \mathrm{g} /$ $\mathrm{L}$ after electrolysis (Table 2). Even by-products were generated, their concentrations were well below the abovementioned limits.

Generation of AOX is triggered by oxidation of chloride (Haaken et al. 2012). A decrease in chloride levels was noted in both water matrices, which probably contributed to the formation of AOX in the wastewater matrix. However, in the WWTP effluent, AOX concentrations were present in the $\mu \mathrm{g} / \mathrm{L}$ range compared to chloride losses, which were in the $\mathrm{mg} / \mathrm{L}$ range. Thus, formation of free chlorine as well as chlorate and perchlorate by the oxidation of chloride ions seems to be possible.

Also other toxic organic and inorganic reaction by-products such as trihalomethanes (THM), bromate or other halogenic compounds appear under high ozone and $\mathrm{OH}$ radical concentrations in halogenide-rich water (von Gunten 2003b; Imo et al. 2007). Disinfection by-products can be suppressed by shortening the treatment times (e.g. when applying higher current densities) or treating a chloride-containing water. Hence, it is crucial to find the balance between optimum conditions for the disinfection process and the inhibition of unwanted reaction by-products, especially in complex water matrices (von Gunten and Pinkernell 2000).

\section{Conclusion}

The current findings show that variation of electrode parameters as well as the water matrix does influence both ozone generation as well as the bacterial disinfection mechanism. In drinking water, the applied current density stipulated whether disinfection was caused by ozone or $\mathrm{OH}$ radicals. Complex water matrices exhibited a different, probably chlorine-driven disinfection mechanism, so that disinfection efficiency remained comparable to that in drinking water. The rapid inactivation of both, gram-negative and gram-positive bacteria, indicates that the BDD electrode seems to be applicable for various disinfection purposes. Significant differences between the three bacteria strains could not be detected. Further research should mainly focus on elucidating the exact disinfection mechanism and the impact it has on other microorganisms, including yeasts, spores and viruses. Further development of the reactor and the BDD electrode design will contribute to improve the disinfection process and at the same time reduce the amount of undesired compounds.

Acknowledgments This research was supported by the Federal Ministry of Education and Research of Germany (03X0087G). The authors want to thank the Institute of Microbial Ecology, Technische Universität München, for their support with the bacteria cultures.

\section{References}

Andreozzi R, Caprio V, Insola A, Marotta R (1999) Advanced oxidation processes (AOP) for water purification and recovery. Catal Today 53:51-59

Anglada Á, Urtiaga A, Ortiz I (2009) Pilot scale performance of the electro-oxidation of landfill leachate at boron-doped diamond anodes. Environ Sci Technol 43:2035-2040

Anglada Á, Urtiaga A, Ortiz I, Mantzavinos D, Diamadopoulos E (2011) Boron-doped anodic treatment of landfill leachate: evaluation of operating variables and formation of oxidation by-products. Water Res 45:828-838

Bader H, Hoigné J (1981) Determination of ozone in water by the indigo method. Water Res 15:449-456

Bergmann H (2010) Zur Bewertung von Diamantelektroden für die Wasserdesinfektionselektrolyse. gwf-Wasser/Abwasser June 2010:604-613

Burleson GR, Murray TM, Pollard M (1975) Inactivation of viruses and bacteria by ozone, with and without sonication. Appl Microbiol 29:340-344

Caslake LF, Connolly DJ, Menon V, Duncanson CM, Rojas R, Tavakoli J (2004) Disinfection of contaminated water by using solar irradiation. Appl Environ Microbiol 70:1145-1150

Cho M, Chung H, Yoo J (2003) Disinfection of water containing natural organic matter using ozone-initiated radical reactions. Appl Environ Microbiol 69:2284-2291

Cho M, Kim J, Kim JY, Yoon J, Kim J-H (2010) Mechanisms of Escherichia coli inactivation by several disinfectants. Water Res 44:3410-3418

Council Directive 1998/83/EC on the quality of water intended for human consumption. OJ L 330. 05/12/1998:32-54 
Council Directive 2006/7/EC concerning the management of bathing water. L 064. 04/03/2006:37-51

Council Directive 2008/1/EC on integrated pollution prevention and control. OJ L 24. 29.01.2008:8-29

Criegée R (1975) Mechanism of ozonolysis. Angew Chem Int Ed 14:745-752

da Silva LM, Santana MHP, Boodts JFC (2003) Electrochemistry and green chemical processes: electrochemical ozone production. Quim Nova 26:880-888

Eaton AD, Clesceri LS, Rice EW, Greenberg AE, Franson MAH (2005) Standard methods for the examination of water and wastewater, 21st edn. American Public Health Association, Washington, DC

Eliasson B, Hirth M, Kogelschatz U (1987) Ozone synthesis from oxygen in dielectric barrier discharges. J Phys D Appl Phys 20:1421-1437

Elovitz MS, von Gunten U (1999) Hydroxyl radical/ozone ratios during ozonation processes. I. The Rct concept. Ozone-Sci Eng 21:239-260

Figueras MJ, Borrego JJ (2010) New perspectives in monitoring drinking water microbial quality. Int J Environ Res Public Health $7: 4179-4202$

Frontistis Z, Brebou C, Venieri D, Mantzavinos D, Katsaounis A (2011) BDD anodic oxidation as tertiary wastewater treatment for the removal of emerging micro-pollutants, pathogens and organic matter. J Chem Technol Biotechnol 86:1233-1236

Fryda M, Matthée T (2006) Diamantelektroden in der Elektrochemie oder "diamonds are the electrochemists best friend?!". Aktuelle Wochenschau 8b. http://www.aktuelle-wochenschau.de/2006/ woche8b/woche8b.html. Accessed 09 April 2013

Fryda M, Matthée T, Mulcahy S, Höfer M, Schäfer L, Tröster I (2003) Applications of DIACHEM ${ }^{\circledR}$ electrodes in electrolytic water treatment. Electrochem Soc Interface 2003:40-44

Gibson KE, Schwab KJ (2011) Tangential-flow ultrafiltration with integrated inhibition detection for recovery of surrogates and human pathogens from large-volume source water and finished drinking water. Appl Environ Microbiol 77:385-390

Gottschalk C, Libra JA, Saupe A (2010) Ozonation of water and waste water, 2nd edn. Wiley-VCH, Weinheim, pp 38-42

Griessler M, Knetsch S, Schimpf E, Schmidhuber A, Schrammel B, Wesner W, Sommer R, Kirschner AKT (2011) Inactivation of Pseudomonas aeruginosa in electrochemical advanced oxidation process with diamond electrodes. Water Sci Technol 63:2010-2016

Haaken D, Dittmar T, Schmalz V, Worch E (2012) Influence of operating conditions and wastewater-specific parameters on the electrochemical bulk disinfection of biologically treated sewage at boron-doped diamond (BDD) electrodes. Desalin Water Treat 46:160-167

Heim C, Glas K (2011) Ozone I: characteristics/generation/possible applications. Brew Sci 64:8-12

Heim C, Ureña de Vivanco M, Rajab M, Glas K, Horn H, Helmreich B, Letzel T (2011) Ozone II: characterization of in situ ozone generation using diamond electrodes. Brew Sci 64:83-88

Hoigné J, Bader H (1983a) Rate constants of reactions of ozone with organic and inorganic compounds in water-1. Water Res 17:173-183

Hoigné J, Bader H (1983b) Rate constants of reactions of ozone with organic and inorganic compounds in water-2. Water Res 17:185-194

Huber M, Göbel A, Joss A, Hermann N, Löffler D, McArdell CS, Ried A, Siegrist H, Ternes T, von Gunten U (2005) Oxidation of pharmaceuticals during ozonation of municipal wastewater effluents: a pilot study. Environ Sci Technol 39:8014-8022

Hunt NK, Mariñas BJ (1997) Kinetics of Escherichia coli inactivation with ozone. Water Res 31:1355-1362
Imo TS, Oomori T, Toshihiko M, Tamaki F (2007) The comparative study of trihalomethanes in drinking water. Int $\mathrm{J}$ Environ Sci Technol 4:421-426

Jeong J, Kim JY, Yoon J (2006) The role of reactive oxygen species in the electrochemical inactivation of microorganisms. Environ Sci Technol 40:6117-6122

Khadre MA, Yousef AE, Kim J-G (2001) Microbiological aspects of ozone applications in food: a review. J Food Sci 66:1242-1252

Kraft A (2007) Doped diamond: a compact review on a new, versatile electrode material. Int J Electrochem Sci 2:355-385

Kümmerer K, Erbe T, Gartiser S, Brinker L (1998) AOX emissions from hospitals into municipal waste water. Chemosphere 36:2437-2445

Lambert PA (2002) Mechanisms of antibiotic resistance in Pseudomonas aeruginosa. J R Soc Med 95:22-26

Lazarova V, Savoye P, Janex ML, Blatchley ER III, Pommepuy M (1999) Advanced wastewater disinfection technologies: state of the art and perspectives. Water Sci Technol 40:203-213

Lee SH, Levy DA, Craun GF, Beach MJ, Caldera ML (2002) Surveillance for waterborne-disease outbreaks-United States, 1999-2000. Morb Mortal Wkly Rep 51:SS-8

Liu F, He G, Zhao M, Huang L, Qu M (2012) Study on the wastewater disinfection at the boron-doped diamond film electrode. Procedia Environ Sci 12:116-121

Menapace HM, Diaz N, Weiss S (2008) Electrochemical treatment of pharmaceutical wastewater by combining anodic oxidation with ozonation. J Environ Sci Heal A 43:1-8

Michaud P-A, Panizza M, Ouattara L, Diaco T, Foti G, Comminellis C (2003) Electrochemical oxidation of water on synthetic borondoped diamond thin film anodes. J Appl Electrochem 33:151-154

Mtethiwa AH, Munyenyembe A, Jere W, Nyali E (2008) Efficiency of oxidation ponds in wastewater treatment. Int $\mathbf{J}$ Environ Res 2:149-152

Ndjomgoue-Yossa AC, Nanseu-Njiki CP, Kengue IM, Ngameni E (2014) Effect of electrode material and supporting electrolyte on the treatment of water containing Escherichia coli by electrocoagulation. Int J Environ Sci Technol. doi:10.1007/s13762-0140609-9

Pleskov YV, Sakharova AY, Krotova MD, Bouilov LL, Spitsyn BV (1987) Photoelectrochemical properties of semiconductor diamond. J Electroanal Chem 228:19-27

Restaino L, Frampton EW, Hemphill JB, Palnikar P (1995) Efficacy of ozonated water against various food-related microorganisms. Appl Environ Microbiol 61:3471-3475

Schmalz V, Dittmar T, Fischer D, Worch E (2008) Diamond electrodes in decentralized wastewater treatment: electrochemical degradation of the chemical oxygen demand (COD) in wastewater with high organic loads from hardening shops. CIT 80:1545-1550

Schmalz V, Dittmar T, Haaken D, Worch E (2009) Electrochemical disinfection of biologically treated wastewater from small treatment systems by using boron-doped diamond (BDD) electrodes-contribution for direct reuse of domestic wastewater. Water Res 43:5260-5266

Tanner BD, Kuwahara S, Gerba CP, Reynolds KA (2004) Evaluation of electrochemically generated ozone for the disinfection of water and wastewater. Water Sci Technol 50:19-25

Tröster I, Schäfer L, Fryda M, Matthée T (2004) Electrochemical advanced oxidation process using DiaChem electrodes. Water Sci Technol 49:207-212

Ureña de Vivanco M, Rajab M, Heim C, Helmreich B, Letzel T (2013) Set-up and energetic considerations for three advanced oxidation reactors treating organic compounds. Chem Eng Technol 36:1-8 
von Gunten U (2003a) Ozonation of drinking water: part I. Oxidation kinetics and product formation. Water Res 37:1443-1467

von Gunten U (2003b) Ozonation of drinking water: part II. Disinfection and by-product formation in presence of bromide, iodide or chlorine. Water Res 37:1469-1487

von Gunten U, Pinkernell U (2000) Ozonation of bromide-containing drinking waters: a delicate balance between disinfection and bromate formation. Water Sci Technol 41:53-59

Wolfe RL, Stewart MH, Liang S, McGuire MJ (1989) Disinfection of model indicator organisms in a drinking water pilot plant by using PEROXONE. Appl Environ Microbiol 55:2230-2241
Yao Y, Kubota Y, Murakami T, Ochiai T, Ishiguro H, Nakata K, Fujishima A (2011) Electrochemical inactivation kinetics of boron-doped diamond electrode on waterborne pathogens. J Water Health 09(3):534-543

Yates R, Stenstrom M (2000) Gravimetric sampling procedure for aqueous ozone concentrations. Water Res 34:1413-1416

Zhu X, Tong M, Shi S, Zhao H, Ni J (2008) Essential explanation of the strong mineralization performance of boron-doped diamond electrodes. Environ Sci Technol 42:4914-4920 